\title{
THE CHARACTER DEVELOPMENT OF
}

\section{NEVILLE LONGBOTTOM IN THE HARRY POTTER SERIES}

\begin{abstract}
Alvanita
Intisari

Skripsi ini meneliti novel berjudul Harry Potter yang ditulis oleh J.K. Rowling. Novel ini memiliki tujuh seri dan bercerita tentang petualangan Harry Potter di sekolah sihir Hogwarts.Tujuan penelitian ini adalah untuk menganalisa perkembangan karakter Neville Longbottom yang merupakan salah satu karakter pembantu di Harry Potter dan juga untuk mengetahui pentingnya karakter Neville dalam seri Harry Potter. Analisis dilakukan menggunakan pendekatan objektif. Pendekatan ini digunakan untuk menganalisis plot, karakter, dan karakterisasi, sehingga dapat disimpulkan perubahan karakter Neville. Hasil penelitian ini menunjukkan bahwa perkembangan Neville sangat berarti dilihat dari tiap seri.Selain itu, perkembangannya sangat penting untuk plot Harry Potter. Awalnya Neville adalah anak yang pemalu dan penurut, namun pada akhirnya dia menjadi seorang hero.Dia adalah karakter minor, namun dia memiliki peran yang sangat penting dalam plot.
\end{abstract}

Kata kunci $\quad$ : Neville, Karakter, PerkembanganKarakter

\begin{abstract}
This graduating paper examines the novel series Harry Potter by J.K. Rowling. There are seven series telling about the journey of Harry Potter in Hogwarts school of witchcraft and wizardry. The objectives of this paper are to study the character development of Neville Longbottom, a minor character in Harry Potter, and to find his significance in the Harry Potter series. The analysis is conducted with objective approach, focused on changes in Neville's character. The result of this research shows that Neville character changes significantly during the series. Moreover, his development becomes very significant to the plot of Harry Potter. At first, he is obedient and shy, but finally in the end of series he becomes a hero. He is a minor character, yet he has a significant role.
\end{abstract}

Keywords : Neville, Character, Character Development 


\section{INTRODUCTION}

J.K. Rowling is one of the most known writers in this era (1997-present time). Her Harry Potter series tell about Harry Potter's adventures in Hogwarts, a school of Witchcraft and Wizardry. There are seven books in these series, namelly Harry Potter and the Philosopher's Stone, Harry Potter and the Chamber of Secrets, Harry Potter and the Prisoner of Azkaban, Harry Potter and the Goblet of Fire, Harry Potter and the Order of the Phoenix, Harry Potter and the Half Blood Prince, and Harry Potter and the Deathly Hallows. Since the release of the first novel -Harry Potter and the Philosopher's Stone- in 1997, the series of the novel have gained immense popularity and success worldwide. As of June 2008, the series of the novel have been sold more than 400 million copies and translated into 67 languages ("It's All in the Translation"). These book series gain many awards such as Nestle Smarties Book Prize 1997 Gold Medal 9-11 years, British Book Awards 1998, Children's Book of the Year Whitaker's Platinum Book Award 2001, WH Smith People's Choice Book Awards Fiction Category 2003, Royal Mail Award for Scottish Children's Books (best book for readers aged 8-12 years) 2006 ("Awards").

The most famous characters in Harry Potter are Harry potter himself, Hermione Granger, Ronald Weasley, Albus Dumbledore and Voldemort. However, there are other characters who also have important role in the novel. Neville Longbottom is one of them. Neville Longbottom is presented as a shy boy in the first novel. He has an important role here since he is a faithful character to the protagonist, Harry. Neville always helps the protagonist fight against the antagonist, Voldemort. Furthermore, in the end of the novel, he is even able to kill Nagini, one of Voldemort's Horcruxes.
Therefore, it is interesting to analyze Neville's character development.

The objectives of this paper are to examine the development of Neville character and to find the significance of his character in Harry Potter series. The focus of this paper is the character of Neville Longbottom, while the scope of the study is all seven series of Harry Potter. However, only the intrinsic elements are used to analyze the character. Abrams' objective approach is used to analyze Neville character. Objective approach deals only with the text book. It ignores extrinsic elements. According to Abrams in his book A Glossary of Literary Terms,

Objective Criticism approaches the work as something which stands free from the poet, audience, and environing world. It describes literary products as a self-sufficient object, or integer, or as a world in itself, which to be judged and analyzed by "intrinsic" element such as complexity, coherence, equilibrium, integrity, and the interrelations of its component element (Abrams 37).

The research is done by library research method. The primary source is seven series of Harry Potter novel, supported by some other books such EM Foster's, Abram's, and other sources which gives some theory of intrinsic elements and some information dealing with Harry Potter.

All series of Harry Potter are read and the data containing Neville Longbottom character are listed and classified into three aspects of development based on Bloom's taxonomy of learning domain. This taxonomy is borrowed to classify Neville's development because Neville also learns how to live. These three aspects; cognitive, 
affective, and psychomotor become the anvil in classification ("Bloom's Taxonomy of Learning Domains"). However, the classification is not exactly according to Bloom's. The researcher here only takes the general idea of the taxonomy to classify since this paper deals with the text book and does not analyze deeper of the psychological analysis. After the Neville character is examined, it is seen his development from the first until the last series of Harry Potter novel.

\section{PLOT, CHARACTER, AND CHARACTERIZATION}

According to Griffith plot is a pattern of carefully selected, casually related events that contains conflict (44). Abrams defines plot as a structure of action that is meant to achieve certain emotional artistic. He says "the plot in a dramatic or narrative work is the structure of its actions, as these ordered and rendered toward achieving particular emotional artistic effects. Story itself is a mere synopsis of the temporal order of the events incorporated in a work of literature." (224). According to Holman in A Handbook to Literature, plot has several functions; to simplify life, to bring order out of life, and to translate character into actions (337). Rohrberger et al. explain that there are four elements of plot : exposition, rising action, climax (turning point), and resolution (24).

According to Stanton, in his book An Introduction to Fiction plot has two major elements: conflict and climax. There are two general categories of conflict; external and internal. Internal conflict take place within the minds of character, while external conflicts take place between individuals or between individuals and the world external to individuals (the forces of nature, human created objects, and environment) (Stanton 16). According to Holman, there are four different kinds of conflict: a struggle against the forces of nature, a struggle against another person, usually the antagonist, a struggle against society as a force, a struggle for mastery by two elements within the person (98).

Character is most often used to refer a person in fictional story. It is a brief descriptive sketch of personage who typifies some definite quality (Holman 74). Stanton explains in his book $A n$ Introduction to Fiction, character can mean an individual who appears in the story, or the mixture of interest, desire, emotions, and moral that makes up a person (17).

There are various types of character in a novel. According to Potter, there are protagonist and antagonist based on the functions of character. Protagonist is the forefront of the actions. Meanwhile, protagonist is the main person or thing forces the protagonist. The basic point is that protagonist is someone who serves as the center of the story, and the opponent is antagonist (7-8). They are major characters and take important role in the story. However, there are some minor characters, though sometimes not really involved with the action at all, are nevertheless very important to the characterization of major character, plot, and even the whole work. One of these is foil character, who serves to clarify and emphasize by contrast another (Potter, 20-21).

Griffith classifies characters into four types based on the development; round, flat, dynamic, and static (60-61). Dynamic character makes progress of the individual, while static characters remains the same from the beginning until the end of the story. Kenney in How to Analyze Fiction explains that flat character is only one side of him seen. It is kind of stereotype character. Meanwhile, round character is more realistic since all sides of him are seen. He does not only have one characters; it is more complex which is able to surprise the readers (28-29). 
To show a character, the author always uses characterization. According to Griffiths characterization is the author's presentation and development of the traits of characters (60). Abrams explains that there are two types of characterizations: showing and telling. Showing characterization is when the author makes a direct statement about the character. The author describes the personality and tells what the character is like directly not only from external speech and actions of the character, but also through inner thoughts, feelings, and how the character responds to some events. Telling characterizations is when the author does not directly give the information about a character, but the author may use other characters to describe and evaluate the motives of a character (33-34).

\section{CHANGES IN NEVILLE'S CHARACTER}

\section{A. Cognitive Aspects}

In this aspect Neville character is analyzed through his mindset, and his capability in acquiring knowledge. In this section, his development in cognitive aspects is divided into three categorizations: concentration, memory, and problem solving.

\section{Concentration}

Neville is described as a student who lacks concentration. He is terrible at everything since he cannot focus on what he is doing. In his first year at Hogwarts, he ruins Potion class taught by Professor Snape. He collapses the cauldron and spills the potion away because he cannot understand the instruction. Professor Snape gets angry at him and calls him an idiot (Rowling, HP-PS 103). Not only in his first year, he even ruins Potion class in his third year at Hogwarts. Due to his lacks of concentration, he cannot brew the potion correctly and turns it into harmful poison. Therefore, he becomes a perfect target for professor Snape's anger. He gives Neville some punishments to make him understand that brewing potion needs full concentration in order not to make it harmful. Professor Snape also takes scores off whenever Neville causes a mess (HPPoA 95-96).

Neville also ruins other classes such as Divination and Transfiguration classes. In Divination class, he breaks a cup which tells fortunes many times. This makes him look like he has bad fortune (HP-PoA 81-82). Meanwhile, in Transfiguration class, he finds difficulties to cast spells correctly. In this class, students should have a clear focus on the subject. Otherwise, the transfiguration will not work properly, and it will harm them instead. Neville nearly harms himself because he casts spells incorrectly. In one such accident, he transplants his own ears onto a cactus (HP-GoF 260).

Although he is terrible most at everything in his early years, he tries to cover his weakness. Step by step, he also gets some assistance from teachers and students. He tries to spell correctly during the class of Defense Against the Dark Arts taught by Professor Lupin. He tries to turn Boggart into something funny using Ridikkulus spell. Finally he can do it by some help of Professor Lupin. Here, Professor Lupin gives him trust to cast a spell and he does not listen to Snape's underestimation on Neville (HP-PoA 100). He even can turn the Boggart twice and it works well. He also earns score for Gryffindor due to this (HP-PoA 105). This shows that he changes step by step, and he also gains some confidence in himself.

In his fourth year, Neville finds his strength. He masters one of the subjects in Hogwarts. It is Herbology taught by Professor Sprout. He even can be classified as one of the best in this class. His cleverness in Herbology is admitted by other students and Professor Sprout, as well as other teachers (HP-GoF 242). This is a great development in Neville. He 
achieves some good acclaims from teachers. Now, he has something to be proud of after his mastery of Herbology. Here, he can prove to others that he is not as terrible as they think.

Neville changes for the better gradually. In his fifth year at Hogwarts, he also joins Dumbledore's Army, a community founded by Harry Potter to learn and practice spells in Defense Against the Dark Arts. This community works secretly in the hidden room called Room of Requirement since any organization and community are not allowed by Dolores Umbridge. Joining Dumbledore's Army, Neville shows better change in his ability. Here, he is able to master the spells after he has worked hard. $\mathrm{He}$ can focus on casting spell and producing some difficult charms such as Patronus. Some of students are not able to produce that, yet Neville can do it. He demonstrates noteworthy improvement on casting spell. He even improves faster than anyone else, except Hermione Granger (HP-OoP 488).

This proves that Neville has changed. $\mathrm{He}$ is not the old Neville described in the first book. He is no longer a troublemaker who lacks concentration. From the previous excerpts, it can be seen that Neville has developed and he is able to manage his concentration. This makes an important difference in his life as to make people no longer underestimate him easily. He achieves what he should achieve and he throws peoples' bad expectations of him away. In the end, Neville becomes more capable as he grows up because he learns about himself and has support from others.

\section{Memory}

Neville Longbottom also has trouble with his memory. He hardly remembers anything, even the simplest thing. He never remembers the password to enter Gryffindor common room, and he cannot remember the subjects he learns. His bad memory is worse than the others students'. It becomes worse as he does not have good concentration either. This makes him seem to be the most miserable student in his year (HP-CoS 68). In Harry Potter series, he is clearly described as a forgetful boy and has trouble with memories. "He also ran into the real Neville Longbottom, a round-faced, forgetful boy, outside Flourish and Blotts" (HP-PoA 46). This shows that he is certainly a forgetful boy. However, as time goes by, his forgetfulness begins to disappear.

In his first year, Neville gets a Remembrall. It is kind of a ball which will turn red if he forgets something. When Neville accepts it, it turns into red which means he forgets something, and unfortunately he does not remember what he forgets (HP-PS 108). This shows that he is a forgetful boy. Even, his habit as being forgetful has been recognized by his Gran. Therefore, his Gran never trusts him even for a simple responsibility. For example, she does not trust Neville to bring permission letter by himself. She sends it directly to Professor McGonagall to make sure Neville will not lose it (HP-PoA 113).

Moreover, Neville never keeps the password to get into common room. He is always locked outside the door since the Lady in the portrait of the door, the password keeper, will not let every student who does not know the password to get into it. Therefore, Neville always wait for others to unlock the door (HP-PoA 74, 184). As time goes by, he tries to cover this weakness. He tries to overcome his forgetfulness. When he is not able to memorize the password, he writes them down to make it easier to get into the common room. Unfortunately, due to his carelessness, this leads to another problem. He drops his note somewhere, and it is found by Sirius Black, a murderer who wants to get into Gryffindor room. He makes Gryffindor room in a mess and he gets detention due to it (, HP-PoA 184). 
Actually, he has found great solution to decrease his forgetfulness, yet has not managed it well. Therefore, he gets great risk when he drops it accidentally. However, this proves that he changes for the better.

In the beginning, as mentioned before, Neville is not trusted even for simple things. In the end of the series, he is finally trusted even for a big responsibility. It shows that he has grown a great deal in managing his weakness. He changes for the better, and he can be trusted. When the Hogwarts is in a war, he is trusted by Harry Potter to kill one of Horcruxes i.e. Nagini. At first, Harry is not sure about giving this responsibility to him, but Neville proves worthy of this trust. He can kill Nagini, and it helps Harry kill Voldemort (HP-DH 557).

3. Problem solving

Since Neville is not good at memory and concentration, it affects the way he thinks too. He is not good at problem solving. He rarely performs the logic thing to solve problem. However, the most he does to solve problem is nothing. He keeps silent so he can escape from the problem, then runs away and does nothing. He tries his best not to be in trouble, and when he faces a problem, he only escapes instead of trying to solve the problem. If he tries to solve it, it will lead to illogical thing.

When a rumor spreads that there is a big monster lies in Hogwarts will kill anyone who is not pureblood, Neville is panicked since he realizes that he was considered as Squib. This is strange since he knows that he is pureblood but he is afraid that the monster will think that he is not pureblood. Therefore he protects himself by wearing a large, evil-smelling green onion, a pointed purple crystal and a rotting newt tail (HP-CoS 139). This thing is not normal even for wizards. Therefore, it indicates he is simple-minded and does not think twice to solve problem. However, most of the time, he does not wish to have problems. He prefers to stay away from them.

In short, Neville has changed significantly seen from the cognitive aspect. He was a forgetful boy, and could not focus, yet eventually he is able to be someone mastering Herbology. He learns from his weaknesses, and tries to manage them. He knows his strength and develops it to help himself and others. He also gains some motivation from friends and teachers, so that he can move on to be a better person. Eventually he can be trusted for responsibility, even for big responsibility.

\section{B. Affective Aspects}

In this aspect, Neville character is analyzed based on his emotion: how he manages emotion, how he expresses his emotion and how he views life and love. During the series, it can be seen how he changes his perspective, and how he learns to express his emotion.

1. Perspective of Life

Neville loves peace. He does not want any trouble although sometimes his carelessness leads to troubles. Most of his years at Hogwarts, he becomes a perfect target for Malfoys's pranks. Malfoy and his friends always bully Neville such as targeting him for a Leg-Locker curse, that makes him unable to walk to his common room since his legs stuck together (HP-PS 160). However, he does not complain and he moves on with life since he does not want any other problem. For him, keeping silent is better than revenge. He is fine as long as he can live in peace. He does not care if he is always bullied as long as it will not lead to another problem. If he has problems, he better escapes from it and to get peace, not to gain victory. He perceives other people as more important than him.

Moreover, Neville is kind of person who does not break established rules since uncomfortable feeling shadows himself if he does that. He also does not let his 
friends to break rules either. He warns Harry, Hermione, and Ron when he knows that they are trying to sneak outside room in the night. The rules do not allow students to go outside room for any reasons. In his first year, Neville warns them twice. When they are going to release Dragon, Neville tries to warn him because he thinks that this only Malfoy's trap. Therefore, he comes to Astronomy tower with Prof. McGonagall to warn them. However, Neville's good intent does not gain positive effect, and he gets detention. He feels bad of himself (HP-PS 177-178). The similar thing happens when he warns Harry and friends again from sneaking outside. Actually they want to save Philosopher's Stone, yet Neville knows nothing of it, and therefore he prevents them. As a result, Neville is petrified by Hermione (HP-PS 198-199).

In his earlier years, all he wants is peaceful life; no matter he suffers or is bullied by others. As time goes by, this perspective changes gradually. He still wants peaceful life but in different way. He realizes that he is allowed to fight back when people hit him, or he can break rules for some favors and at the right time. Sometimes rebellion is needed to make others understand that he is also as worthy as others. He begins to stand up for himself. He fights back when Malfoy bullies him (HP-PS 163). He is encouraged by his friends since keeping silent will keep Malfoy doing the bad behavior.

Neville learns that no one can underestimate him because all people have their weakness and strength, so does Neville. When Bellatrix Lestrange, Death Eaters who tortures his parents, mocks him, he gets angry and fights her (HP-OoP 706). He does not keep silent and does nothing. He fights back when he thinks that is the right thing. However, he will not ignite conflict unless others start first.

During his fifth year, Neville is no longer an obedient boy. He starts breaking established rules. He thinks that breaking rules for a right thing and at the right time is fine. He joins Dumbledore's Army although he has understood that any students' organizations are disbanded and those who works on it will get punishments (HP-OoP 323). Neville does not care of it because this is the only place he can learn how to defense against Voldemort and Death Eaters.

In his seventh year, Neville breaks rules more often. He does not follow the rules of Carrows Brother, Death Eaters who be teachers in Hogwarts, since he thinks they are not capable to be teachers. Moreover, they torture the students and teach in cruelty. He does not respect them and do not want to be under their control. When he is instructed to practice Cruciatus curse to others, he declines that since it is not used to harm others, and therefore he gets some cruel punishments (HP-DH 461462). However, he does not suffer of that. He wants to be free and save Hogwarts and his friends from Death Eaters' cruelty. $\mathrm{He}$ leads his friends to hide in the Room of Requirement in order not to be tortures. They make some plans to save Hogwarts, and Neville become the initiator; taking charge of Dumbledore's Army.

In short, Neville changes gradually. $\mathrm{He}$ is no longer an obedient boy. He teaches others that they should not torture, mock, and underestimate people who have lots of weaknesses. All people have right to defend themselves, and so does he, as Neville finally realizes.

2. Perspective of Love

Here, Neville character is analyzed through his love to his family, friends, and Hogwarts. At first, Neville is ashamed to have parents like his parents since they are insane and cannot fulfill their parental roles. He envies other students who can easily communicate with their parents. Meanwhile, Neville can only visit his parents in St. Mungo Hospital since his parents are tortured by Death Eaters and 
become insane. They even do not recognize Neville as their son. They are not able to talk (HP-GoF 655). This makes Neville miserable and insecure. Moreover, his Gran always compares him to his father. Actually his parents were great Aurors, yet now they can only lie powerlessly in bed.

Nevertheless, Neville loves his parents so much. As time goes by, he realizes that his parents are the best he has in this life. He appreciates everything given by his parents, and he is proud of them since they have sacrificed their lives to save Neville. He does not want to hurt their heart if they know he feels ashamed of them. At first, Neville never talks to his friends about his family, however when he realizes how precious his parents are, he starts to admit that his parents are in Hospital and he does not feel ashamed of that (HP-OoP 624). The power of love gives Neville the power to improve himself. He realizes he cannot be what his father was, but he believes he can be greater by being himself. This motivates him to change his attitude and manage his weakness.

Neville also gains love from his friends although actually in his early years, he does not have "real" friends whom he can talk to. Having friends encourages him to help them and stand up for them because his friends also do the same things when he faces problems. He insists to help Harry when he knows that Harry is going to save Sirius Black from Voldemort. He has known that it is very risky for him, yet he does not care. For him, one should help a friend with all his strength (HP-OoP 671).

Not only helping friends, he also stand up for Hogwarts. He does not let Voldemort and Death Eaters destroy Hogwarts. When he sees Voldemort's signal in the sky, he begins to watch Malfoy as Harry has instructed him to. He tries to save Hogwarts with all his strength and he fights against Malfoy and Death
Eaters, though finally he ends up in Hospital due to some injuries (HP-HBP 576-577).

In the last series of the novel, Neville also save his friends and Hogwarts from Death Eaters' cruelty. During the Battle of Hogwarts, he fights against the Death Eaters to save everyone he loves. He changes entirely. He becomes a hero for his friends, family, and Hogwarts, and therefore people proud of him. His Gran eventually admits that Neville is great to be himself (HP-DH 502). Here it can be seen that the power of love is able to motivate someone to change for the better.

\section{Psychomotor Aspect}

In this aspect, Neville is analyzed through the way he speaks. Actually, Psychomotor deals with the development of the way he walks, runs, jumps, and organizes his body. However, there is no description in the novel and therefore it is not analyzed.

Neville always speaks in a low voice and does not snap at others. He is so careful with his words; not to hurt others' feeling. It seems that he is not confident enough to express his feelings and thoughts. He also speaks nervously and in unclear intonation. His face often turns red when he speaks. He often mumbles and does not want to argue (HP-OoP 397).

Sometimes, Neville speaks in happy clear tone, yet it occurs rarely when he is in happiness. He is often filled with misery since he realizes that he causes a lot of problem he does not want. Sometimes, he also speaks in higher voice which means something wrong with him. This happens when Dementor attacks Hogwarts Express (HP-PoA 67), and the time when Alastor Moody practices Cruciatus Curse in class which reminds him of his parents misery (HP-GoF 240).

Through a process, Neville learns to change. He becomes brave enough to state arguments in clear tone. He even able 
to insists other to do what he says. He no longer mumbles and speaks nervously. He is able to argue and defend himself. He can argue back when Malfoy mocks him. He can make Malfoy speechless of his words (HP-PS 163). Not only to Malfoy, he even can do that to his friends who want to break rules. It shows that he changes better. Eventually, he can argue to Voldemort when he invites Neville to join Death Eaters. For Neville, joining Death Eaters is a betrayal for Hogwarts (HP-DH 586). It is seen that Neville changes gradually. He becomes braver and braver. No one expects strong words from him since he always mumbles and speaks nervously. However, through process, he can manage his weakness.

From the analysis, it can be concluded that Neville's character changes gradually. His change is significant in cognitive and affective aspects, although his psychomotor aspects do not change as significantly.

\section{The Significance of Neville's Character}

Neville is not the main character in the Harry Potter series, and he does not appear frequently. However he plays a significant role here to the plot and to other characters. In the story, it is told that Neville and Harry have the same qualities to be the chosen one according to the prophecy. They are similarly born in the end of July. The prophecy only works for one person, and fate turns in favor of Harry Potter. As time goes by, Harry and Neville has some similarities such as that both of them are orphans, though Neville is not literally an orphan. He only does not receive the proper son-parent relationship. Both Harry and Neville also come to Hogwarts without any prior knowledge of magical things.

Nevertheless, Neville helps Harry obtain his fortune. Accidentally, Neville's Remembrall leads Harry to be the youngest seeker because Prof. McGonagal recognizes his skill when he is catching Remembrall in the air. Neville also helps Harry to solve Harry's quest in the Triwizard Tournament. Neville gives him Gillyweed, that enables Harry to breathe under water for thirty minutes and accomplish the challenge. Moreover, Neville also helps much when Death Eaters attack Hogwarts in his sixth year. Neville is the only one who realizes Harry's summon using the DA's coin, and he tells other friends to be ready for the attacks. His role becomes more significant in the last series. He seems become the center in Hogwarts because he is the leader of his friends to gather power and plan for the rebellion against Death Eaters. Meanwhile, Harry focuses on destroying Horcruxes outside Hogwarts. Neville gains attention not only from friends, but also teachers, Death Eaters, and even Voldemort. In the end of the series, the peak point, Neville is able to help Harry to kill Nagini, one of the Horcruxes. He kills it using the Gryffindor Sword that he has pulled from the Sorting Hat (HP-DH 587).

These incidents show that Neville's character development leads him to take a significant role in the story. If he remains the same, as a forgetful, idiot and obedient boy, he will not be able to kill Horcrux, and even he will only stay in his room when Death Eaters attack Hogwarts. However, he is able to improve. He proves he can be given a big responsibility. He is no longer a forgetful and obedient boy. He can be a hero, a leader for his friends, and he can help his friends, family, and Hogwarts. He turns into a new Neville Longbottom. No doubt, ten years after the Battle of Hogwarts, he becomes a great Professor in Hogwarts (HP-DH 606).

Actually, it is not a wonder if he eventually can be a great person. He is in Gryffindor and he is destined to be a hero. In the first he is more suitable to be in Hufflepuff where loyalty is needed, instead 
of being in Gryffindor who lacks bravery (HP-PS 88). No one expects that Neville is suitable for Gryffindor since he does not have bravery. However, as time goes by, the Sorting Hat is right. Neville is best classified in Gryffindor, and even Neville can pull out the sword from Sorting Hat which means he is true Gryffindor because only the true one who can do that (HP-CoS 245).

In the Harry Potter series, Neville is a foil character. He is only a minor character yet has a significant role. $\mathrm{He}$ becomes a contrast to Harry Potter. He can survive from bullying, and he can manage his weaknesses by his effort and assistance from others. It can be said that his changes are more significant than Harry since Harry can overcome everything by some helps from everyone. Harry has friends who always stand beside him, and he is destined to be the one who will conquer the Dark Lord. Therefore, there will always people who will help him. However, Neville does not have it all, and he has to have great effort to survive. He eventually can overcome that and turn to be a hero. Neville fulfills his function as foil character here because he makes the protagonist, Harry, become more and more interesting and likeable than other characters.

Neville character is dynamic and round because he does not only have one stereotypical character and he does not remain in one character. He develops as he learns from experiences. At first, he is forgetful boy, yet in the last he is a hero. Neville character is a little bit complicated for a minor character. His character is round because he is not simply can be said as a shy and kind boy. Sometimes, he changes to be brave boy and break rules often. His character changes due to the situation. From the previous section, it can be seen how he develops in three aspects and it shows that he is dynamic and round.

\section{CONCLUSION}

Unlike Harry Potter, Neville Longbottom is not the main character in this series, yet he takes significant roles due to his developments. He becomes a completely different Neville from the one appearing in the first series. He is no longer a shy, forgetful, and obedient boy as described in his early years in Hogwarts. His development is classified into three aspects; cognitive, affective, and psychomotor. It can be seen that he has managed his weakness in forms of memory and concentration. Therefore, he can learn quickly and decrease his forgetful memory. $\mathrm{He}$ also masters Herbologywhich makes him more confident. He changes his perspective and therefore he views life should be peaceful but does not mean that he can be bullied by others and suffers. He learns sometimes fighting back is needed to make people realizes that he is as worthy as others. He becomes braver, and he is able to speak clearly, as well as he argues to defend.

These developments happen because he eventually finds motivation to change better. He loves and cares for his family, friends and Hogwarts. He also gains support from them, and they encourage him to change better. He wants to save them, and wants to prove that he can be a great person in his own way and to be himself. In brief, it can be said that Neville character is unique. Despite the fact that he is minor, he plays significant role to the plot. He develops well, so that in the end, he is able to fight against Voldemort and Death Eaters, and therefore he gives the Harry Potter series a happy ending. 


\section{BIBLIOGRAPHY}

Abrams, M.H. A Glossary of Literary Terms.USA :Heinle\&Heinle, a division of Thompson Learning Inc., 1999. Print.

"Awards".Harry Potter. Bloomsbury, 2010.Web. 15 November 2013. $<$ http://harrypotter.bloomsbury.co m/author/awards>

"Bloom's Taxonomy of Learning Domains". Big Dog and Little Dog's Performance Juxtaposition.Web. 11 February 2014

$<$ http://www.nwlink.com/ doncla rk/hrd/bloom.html $>$

Foster, E.M. Aspects of the Novel. London :Buttler and Tanner Ltd., 1953. Print.

Griffiths, Kelly. Writing Essays about Literature: A Guide and Style Sheet. New York : Harcourt Brace Jovanonich, Inc., 1986. Print

Holman, C. Hugh. A Handbook to Literature $3^{\text {rd }}$ ed. Indiana Polis : the Bobs Merril Company, 1980. Print

"It's All in the Translation". Harry Potter. UToday news, 23 February 2010.Web. 12 June 2013 <https://www.ucalgary.ca/news/ut oday/february232010/harrypotter>

Kenney, William. How to Analyze Fiction. New York : Monarch Press, 1966. Print

Potter, James L. Elements of Literature. New York : The Odysey Press Inc., 1967. Print.
Rohrberger, Mary, Samuel H. Woods, JR., and Bernard F. Dukore.An Introduction to Literature. New York : Random House Inc., 1968. Print.

Rowling, J.K. Harry Potter and the Chamber of Secrets.London : Bloomsbury, 1998. Print. . Harry Potter and the Deathly Hallows. London : Bloomsbury, 2007. Print. . Harry Potter and the Goblet of Fire.London : Bloomsbury, 2000. Print. . Harry Potter and the Half Blood Prince.London : Bloomsbury, 2005. Print. . Harry Potter and the Order of the Phoenix.London: Bloomsbury, 2003. Print.

. Harry Potter and the Philosopher's Stone.London : Bloomsbury, 1997. Print.

. Harry Potter and the Prisoner of Azkaban.London : Bloomsbury, 1999. Print.

Stanton, Roberts. An Introduction to Fiction.New York : Halt, Rinehart and Winston inc, 1965. Print. 